\title{
Pelatihan Program Inspiring Teaching Bagi Guru-Guru SDN Sangkanwangi 1 Dalam Mengatasi Kesulitan Pembelajaran Daring
}

\author{
${ }^{1}$ Ajeng Muliasari, Didin Saprudin ${ }^{2,}$ Salman Sunardi ${ }^{3,}$ Yeni Sulaeman ${ }^{4}$ \\ STKIP Syekh Manshur \\ e-mail: ${ }^{1}$ didinsaprudin012@gmail.com, 2muliasariajeng1@gmail.com, \\ ${ }^{3}$ salmansunardi60@gmail.com, ${ }^{4}$ yenisulaemananesta@gmail.com
}

\begin{abstract}
Abstrak
Berdasarkan hasil observasi guru di SDN Sangkanwangi 1 Kecamatan Leuwidamar, mereka kesulitan mengajar secara online. Hasil observasi server menunjukkan bahwa keterampilan mengajar dalam aspek pengetahuan, keterampilan maupun sikap, sangatlah penting dan menjadi keterampilan dasar yang harus dimiliki guru dalam menjalankan fungsinya, ternyata perlu dilatih kembali untuk meningkatkan motivasi mengajar. Masih ada guru yang kesulitan menggunakan dan menggunakan pembelajaran berbasis teknologi karena kurangnya keterampilan dan pengetahuan atau Gaptek. Melalui program pelatihan dan pembinaan yang inspiratif bagi para guru untuk mengatasi kesulitan belajar online tersebut, para guru di SD Negeri 1 Sangkanwangi diharapkan mampu memodifikasi metode pengajarannya sesuai dengan kondisi dan keadaan, selanjutnya mereka berharap guru lebih fleksibel. dan terampil dalam mengajar sesuai dengan perkembangan zaman. Penerima pengabdian ini adalah para guru SDN Sangkanwangi 1 Kecamatan Leuwidamar. Metode yang digunakan adalah observasi, survey sekolah dan wawancara dengan pimpinan sekolah. Program tersebut disampaikan dengan memberikan pelatihan dan kemudian melanjutkan pendidikan terkait topik yang dibutuhkan mitra untuk mempersiapkan guru mengatasi permasalahan pembelajaran online. Hasilnya adalah pemahaman semua guru dalam menerapkan metode pengajaran inspiratif kepada siswa di kelas.
\end{abstract}

Kata Kunci: inspiring teaching, pembelajaran daring, kompetensi guru

\section{Abstract}

Based on the teacher's observation at SDN plant's scent 1 leuwidamar district, they had difficulty teaching online. As the result of server observation shows, teaching skills in both aspects of knowledge, skill and attitude are essential and become a basic skill a teacher must have in exercising them, only to be retrained in order to increase teaching motivation. There are still teachers who struggle to use and use technology-based learning because of lack of skill and knowledge or techno-tech. Through inspiring training and coaching programs for teachers to cope with the difficulties of online study, teachers at public school 1 sangkanscented is expected to modify his methods of teaching according to conditions and circumstances, and they, in turn, expect teachers to be more flexible. And skilled in teaching 
according to the age at hand. The recipient of this devotion is SDN's SDN boasts 1 leuwidamar district. The methods used are observation, school surveys and interviews with school directors. The program is presented by providing training and then continuing education on topics needed partners to prepare teachers for the problem of online learning. The result is an understanding of all teachers in applying inspiring teaching methods to students in the class.

Keywords: inspiring teaching, online learning, teacher competence

\section{Pendahuluan}

Pendidikan merupakan sumber perkembangan peradaban manusia, dan saat ini proses pendidikan terus mengalami kemajuan. Sistem pendidikan merupakan hub sentral untuk pengembangan generasi berikutnya. Guru sebagai salah satu sumber daya manusia di lingkungan pendidikan merupakan aktor utama yang memegang peranan penting dalam pendidikan peserta didik dan semakin berkembangnya kebutuhan untuk mengembangkan keterampilan dan kompetensinya bagi pendidikan peserta didik di sekolah. Dalam jurnal tersebut (Sutarman et al., 2019) ia mengatakan bahwa inovasi sangat penting ketika menghadapi tantangan dan sangat penting untuk menemukan solusi dan menerangi mereka dengan ide-ide baru, mendalam dan progresif. Hal ini menjadikan inovasi untuk meningkatkan dan memperkuat aspek pendidikan lebih efektif, efisien dan produktif.

Semakin meningkatnya tantangan dalam menjalani peran sebagai guru atau pendidik saat ini, sepertinya memang dipersiapkan jika dihadapi oleh keadaan tertentu seperti saat ini, adanya pandemic yang melanda Indonesia bahkan dunia. Keadaan ini menuntut guru untuk menggunakan kompetensinya dalam mengajar dengan segala kondisi. Menurut Dohman dalam(Kahfi, 2020), pembelajaran di masa wabah adalah melalui pembelajaran jarak jauh (PJJ), yang meyakini bahwa pembelajaran jarak jauh adalah bentuk pembelajaran mandiri dan sistematis di mana sekelompok guru yang bertanggung jawab melakukan berbagai upaya.

Keadaan pandemik ini pun dirasakan oleh sekolah di Kecamatan Leuwidamar Desa Sangkanwangi, perubahan system pendidikan karena pandemic merubah segalanya. Belajar tatap muka yang beralih ke daring atau online ternyata menimbulkan banyak hambatan dan permasalahan yang terjadi dan harus dihadapi oleh guru maupun siswa. Hambatan yang dirasakan adalah siswa kurang memahami materi, siswa kehilangan minat dalam belajar, guru kebingungan dan merasa kesulitan dalam mengajar daring, guru terbiasa mengajar dengan cara ceramah langsung dan "menyuapi" siswa.

Berdarakan hasil wawancara dengan guru kelas 6 SDN 1 Sangkanwangi di peroleh : Guru sudah mempersiapkan RPP sebelum mengajar pembelajaran daring RPP daring juga sudah ada tinggal di kembangkan oleh gurunya sendiri. "Kami menggunakan Whatshapp dalam menyampaikan pembelajaran, akan tetapi kami masih menerima tugas yang di antar kerumah atau ke sekolah karena banyak kendala yang di hadapi oleh orangtua murid ada yang kurang memehami cara 
mengoprasikan HP Anroid dan jaringan yang tidak mendukung", menurut hasil wawancara dengan salah satu guru.

Dengan meningkatkan kekuatan komunikasi dengan siswa di rumah, guru juga menggunakan program untuk menyampaikan pembelajaran. Dalam hal komunikasi, ini hanya berjalan di grup WhatsApp tanpa zoom karena sinyal yang buruk dan kurangnya pengetahuan tentang penggunaan teknologi. "Kami hanya berkomunikasi dengan siswa melalui whatsapp. Ketika siswa mengerjakan pekerjaan rumah di rumah atau di sekolah, mereka mungkin bertemu tatap muka saat masuk rumah pada hari Senin dan Rabu. Proses belajar di rumah membutuhkan kendala untuk keduanya. Kapan membagikan materi kepada siswa dan mengumpulkan pekerjaan rumah.Sebagian besar siswa tidak mengerti bagaimana menggunakan teknologi. Ada dua cara untuk memberikan pekerjaan rumah dan mengumpulkan pekerjaan rumah. Hal ini akan membuat siswa tidak dapat mengikuti proses pembelajaran selama wabah pandemi 19 .

Melihat kondisi tersebut, pengajaran inspirasi atau inspiring teaching akan membantu siswa mampu belajar secara mandiri dan termotivasi secara sadar untuk belajar dirumah tanpa harus terpantau oleh gurunya selalu. Pada Penelitian yang dilakukan oleh (Slameto, 2015) Guru yang inspiratif adalah guru yang mengubah pembelajaran tradisional sehari-hari, mekanis menjadi proses pembelajaran yang dinamis, interaktif, demokratis, bermakna, dan memberdayakan.

(Rohani, 2013) dalam penelitiannya mengatakan pemerintah telah Mendaungkan konsep pembelajaran yang menarik bagi guru merupakan solusi dari permasalahan yang berkaitan dengan kemauan belajar dan kemauan belajar siswa. Penelitian yang lain mengatakan, terkait dengan definisi dan hasil yang digunakan secara eksplisit dan implisit dalam literatur yang ada menunjukkan kerangka kerja untuk pemahaman pengajaran yang menginspirasi bergantung pada hal-hal berikut: hasil positif siswa (misalnya motivasi, efikasi diri, aspirasi, prestasi; keduanya lama dan efek jangka pendek), perilaku dan praktik guru tertentu, karakteristik guru (misalnya sifat kepribadian, pengetahuan, dan motivasi) dan hubungan. (Pamela Sammons , Ariel Mariah Lindorff , Lorena Ortega, 2014)

Dalam penelitian awal yang dilakukan oleh peneliti sejak Juli 2021 dapat diuraikan bahwa proses kegiatan belajar mengajar terhitung dari tahun ajaran 2021-2022 Ganjil adalah adalah blended learning dimana siswa sudah bisa belajar tatap muka terbatas sesuai dengan jadwal yang sudah diatur oleh sekolah.

Melihat kondisi ini, peneliti melakukan rencana pelatihan untuk guru agar mulai mengubah metode mengajarnya dengan pengajaran yang menginspirasi. Hal ini dibuat untuk mendorong minat alami siswa dalam belajar, sehingga saat nanti siswa belajar di rumah tanpa bisa terpantau guru, siswa secara sadar mau untuk belajar. Hal ini dikatakan dalam penelitian (Rohani, 2013) bahwa Metode pembelajaran yang inspiratif merujuk dari teori active learning,fun learning,dst.

Pembelajaran inspiratif yang menyenangkan dituliskan dalam penelitian (Williams et al., 2016) dimana kegiatan pengajaran inspiratif dapat merefleksikan pengajaran 
yang menginspirasi dan peran guru sebagai pengembang kegiatan pengajaran dapat berperan dalam meningkatkan praktik individu. Pengajaran adalah komponen inti dari Pendidikan Tinggi dan kompleks dan multi-faceted baik secara teoritis dan dalam praktek (Morrison, G. R., Ross, S. M., \& Kemp, 2001) bahwa sebuah pembelajaran menyenangkan dapat di desain secara instruksional dengan proses sistematis merancang, mengembangkan, mengevaluasi dan mengelola seluruh proses instruksional untuk memastikan pembelajaran yang efektif dan efisien. Hal ini didasarkan pada apa yang kita ketahui tentang teori pembelajaran dan pengajaran, desain sistem, sistem informasi dan manajemen. Kemudian dalam penelitian yang dilakukan oleh (Shen, 2012) ada 5 proses yang harus dilakukan dalam desain pembelajaran inspiratif, meliputi motivasi kreatif, penyediaan bahan ajar, melakukan metode berpikir kreatif, melanjutkan diskusi dan umpan balik kreatif, dan evaluasi.

Idealnya, tantangan proses pembelajaran dari rumah ke pembelajaran jarak jauh harus disesuaikan dengan kebutuhan bakat siswa sesuai dengan tingkat pendidikan siswa. Tersedianya sumber daya pendidikan dan dukungan orang tua serta jaringan yang berkelanjutan untuk komunikasi yang efektif antara siswa dan guru (Arifa, 2020).

Hambatan ini juga menghadirkan tantangan pembelajaran jarak jauh sebagaimana mestinya dan dapat memberikan pembelajaran jarak jauh di masa pandemi Covid19 saat ini. Hambatan pembelajaran jarak jauh terkait dengan motivasi guru. Sarana dan prasarana serta dukungan teknis yang lengkap (Basar, 2021).

Melihat dari kedua penelitian diatas, tantangan dan hambatan dalam pembelajaran jarak jauh harus segera diatasi, sesuai dengan kendala yang sudah peneliti uraikan diatas. Berdasarkan observasi di atas, maka peneliti memilih untuk mengadakan pelatihan program inspiring teaching dalam mengatasi kesulitan pembelajaran daring bagi guru di SDN Sangkanwangi 1 dengan langkah dan metode terpadu yang memudahkan guru guru untuk kemudian mengaplikasikannya.

\section{Metode}

1. Survei lapangan

Survei awal ke lapangan sejak awal bulan Juli 2021 selama 2 minggu bertujuan untuk mengamati situasi dan keadaan anak-anak yang sedang melaksanakan pembelajaran daring di Desa Sangkanwangi Kecamatan Leuwidamar.

2. Koordinasi dengan masyarakat

Berkoordinasi dengan pihak RT 001 dan RW 005 kampung palopat desa sangkanwangi dan kepala kelurahan tempat pelaksanaan kegiatan pendampingan. Kemudian melakukan observasi secara sistematis dengan memantau beberapa aspek penting yang terjadi di tempat penelitian sebelum memutuskan program yang tepat untuk diberikan pada masyarakat dan terakhir melakukan wawancara tidak erstruktur pada guru, siswa, dan orangtua. 
3. Sosialisasi program

Sosialisasi program pelatihan inspiring teaching bagi guru dalam mengatasi kesulitan pembelajaran daring bertujuan untuk memberikan informasi tentang rencana serangkaian pelaksanaan program.

4. Pelaksanaan program

Pelatihan program inspiring teaching bagi guru dalam mengatasi kesulitan pembelajaran daring melalui kegiatan pelatihan secara terstruktut dilaksanakan di sekolah SDN Sangkanwangi 1, di hadiri oleh kepala kelurahan, ketua komite, kepala sekolah, pemateri dosen PGSD STKIP Syekh Manshur beserta kaprodi PGSD dan ketua STKIP Syekh Manshur, dan terakhir guru-guru yang ada di SDN Sangkanwangi 1 Kecamatan Leuwidamar Kabupaten Lebak- Banten.

Kegiatan ini adalah pelatihan yang kemudian akan dipantau perkembangannya karena ada tugas berupa membuat analisa perilaku peserta didik dalam belajar, konsep kerangka pembelajaran inspiratif, memilih model dan merumuskan pengaplikasiannya, membuat instrument evaluasi. Kemudian untuk praktiknya yang harus dilakukan oleh para guru adalah menerapkan atau mensimulasikan desain pembelajaran inspiratif yang sudah dikonsep. Berikut adalah penjelasan mengenai alur proses dalam mendesain pembelajaran inspiratif. Setelah memahami alur ini guru akan diberikan tugas dan praktek sesuai dengan alur yang akan dilakukan.

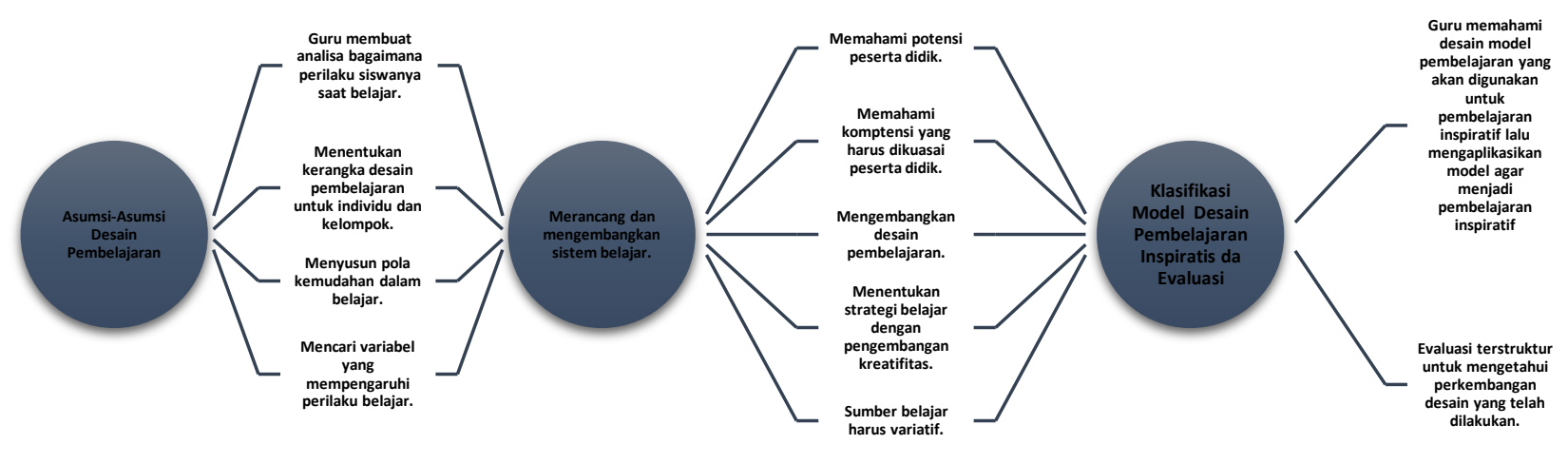

Gambar 1. Alur proses dalam desain pembelajaran inspiratif

Pemateri akan memberikan pelatihan dan kemudian mahasiswa yang terlibat dalam KKN Tematik Mandiri yang berjumlah 6 orang yang kemudian akan membimbing progress para guru dalam pengembangan program inspiring teaching ini. Peserta yang hadir dibatasi dihadiri oleh 15-20 guru, dengan menerapkan protocol Kesehatan covid-19 termasuk mencuci tangan sebelum masuk rumah, memakai masker/face shield, dan menjaga jarak aman. 


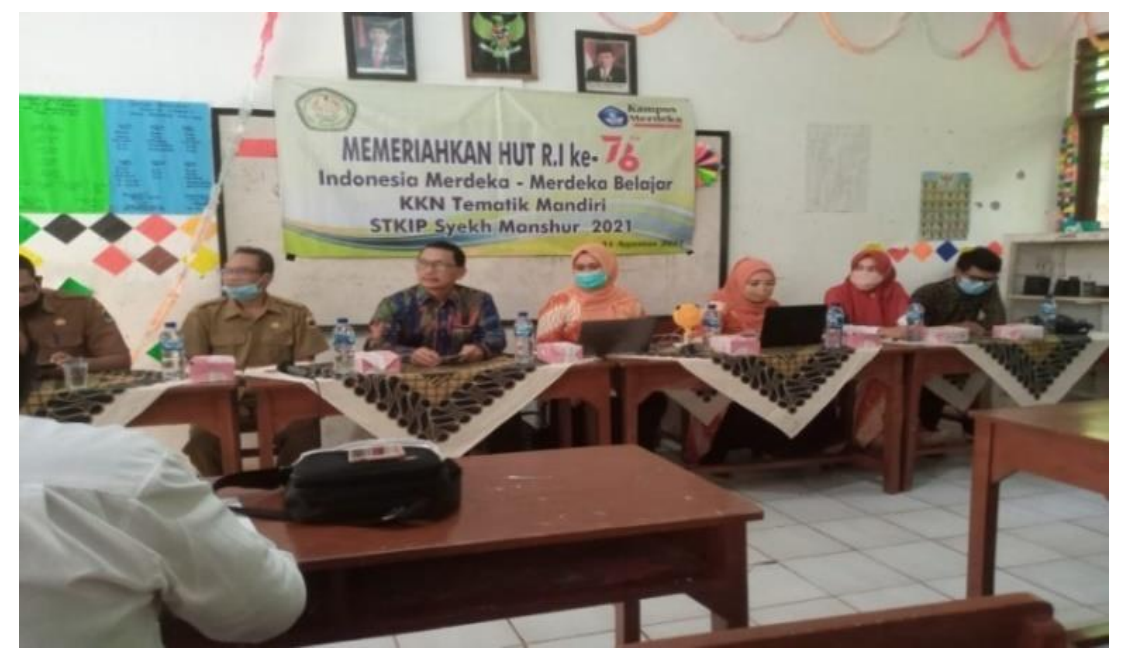

Gambar 2. Pembukaan Kegiatan Pengabdian

Fasilitas yang digunakan untuk mendukung kegiatan tersebut antara lain proyektor, layar, laptop dan notebook, serta beberapa snack sebagai hadiah bagi siswa. Kegiatan ini berlaku sejak observasi dimulai pada Juli 2021 dan berlangsung selama Periode Tematik KKN Mandiri dari 16 Agustus hingga 16 September 2021 yang terjadi setiap minggu. Rasa haus akan tindakan ini menyertai pembelajaran dalam empat fase:

a. Penguatan dengan memotivasi

b. Pemberian materi (soal fisik) dan pembahasan jawaban

c. Pemberian tugas lisan dan tertulis dan latihan latihan

d. Pemberian Hadiah

\section{Hasil dan Pembahasan}

Pada bagian ini pengabdi akan menguraikan pembahasan yang dari kegiatan yang dilakukan pengabdi. Pada observasi awal yang dilakukan pengabdi melalui wawancara tidak terstuktur kepada beberapa guru-guru yang ada di SDN Sangkanwangi 1, yaitu Ibu Sutini. S.Pd, Ibu Hj. Ani Iiskaryati, S.Pd, dan bapak Suhada, S.Pd.I mereka mengatakan kesulitan dan kebingungan bagaimana menghadapi model pembelajaran saat kondisi pandemik, mereka pun kurang akan informasi mengenai model dan tehnik pembelajaran yang dapat memicu semangat siswa untuk belajar. Dari hasil wawancara tersebut kemudian pengabdi menyusun rancnagan kegiatan, berikut uraiannya : 1) Kegiatan pengabdian kepada masyarakat ini adalah program pelatihan pembelajaran inspiring ini dilakukan pengabdi selama kurang lebih 30 hari yang dihitung dari observasi awal, adapun kegiatan pelatihan ini dibagi menjadi 3 pertemuan untuk kegiatan tatap muka dengan team pemateri selebihnya dipantau oleh team mahasiswa KKN yang betugas di desa Sangkanwangi. 2) Kegiatan pertemuan selama 3 kali berlangsung sesuai tahapan bagaimana merancang desain pembelajaran inspiratif, team pemateri akan memberikan pembinaan selanjutnya untuk penugasan akan dibantu oleh mahasiswa KKN dan pelaporan progress para guru - guru di SDN 1 Sangkanwangi pada setiap tahapan, dilaporkan oleh mahsiswa KKN melalui instrument yang diberikan pada guru-guru dan penilaian melalui pengamatan. 
Berikut adalah uraian kegiatan program pelatihan pembelajaran inspiratif bagi guru guru SDN Sangkanwangi 1, selama 3 kali pertemuan dengan team pengabdi guru SDN Sangkanwangi 1 melakukan:

1. Tahapan asumsi- asumsi desain pembelajaran

a. Guru -guru di SDN Sangkanwangi 1 pada tahapan pertama dalam membuat desain pembelajaran inspiratif melakukan pengumpulan data perilaku belajar siswa yang kemudian dianalisis, pada tahapan ini data perilaku belajar siswa dianalisis bersama menggunakan metode small grup discussion. Tujuan dari tahap ini adalah guru perlu memahami pola perilaku siswa dalam belajar sehingga desain pembelajaran inspiratif yang dirancang nanti sesuai dengan kebutuhan siswa.

b. Proses yang kedua, melanjutkan dari hasil analisis pola perilaku siswa dalam belajar kemudian guru menentukan kerangka desain pembelajaran untuk individu dan kelompok. Penentuan kerangka desain ini sebagai konsep dalam pembuatan desain pembelajaran inspiratif. Kerangka desain harus mencakup proses belajar untuk individu dan kelompok.

c. Proses ketiga adalah menyusun pola kemudahan dalam belajar dan mencari variabel yang mempengaruhi perilaku belajar. Di dalam kerangka desain pembelajaran inspiratif guru mengasah metode berpikir kreatif untuk menyusun pola yang akan memudahkan siswa dalam belajar, metode ini akan menginspirasi siswa bahwa materi yang dipelajari tidak sulit dan memancing siswa untuk belajar mandiri karena guru mencari variabel yang mempengaruhi perilaku belajar siswa.

2. Merancang dan mengembangkan sistem belajar.

Pada tahapan kedua ini, terdiri dari 5 proses yaitu : 1)Memahami potensi peserta didik, pada tahapan kedua yang pertama dilakukan adalah guru sudah masuk pada pemahaman potensi peserta didik, potensi yang dimaksud adalah kemampuan kognitif, afektif dan konatif yang unggul pada peserta didik. Selanjutnya 2) Memahami kompetensi yang harus dikuasai peserta didik. Guru perlu memahami mata pelajaran yang diberikan pada siswa berikut dengan kompetensi umum dan khusus yang harus siswa kuasai. Karena dengan pemahaman ini guru bisa mengelola desain pembelajaran inspiratif, dan guru menggunakan potensi siswa untuk merangsang siswa mencapai kompetensi yang harus dikuasai. 3) Mengembangkan desain pembelajaran, pada proses ini adalah inti dari program pelatihan pembejaran inspiratif. Guru merancang desain pembelajaran dengan mendesain ulang RPPnya lalu melatih tehnik pengajaran dan mengupgradenya. Proses mengembangkan desain pembelajaran ini termasuk guru harus menentukan strategi belajar dengan pengembangan kreatifitas, artinya guru akan mengevaluasi pola pengajarannya dan pengabdi nanti akan membantu untuk mengembangkan strategi pembelajaran dengan 
kreatifitas. Terakhir 5) Sumber belajar harus variatif. Guru mencari sumber belajar diluar buku LKS yang lebih terkini dan disukai oleh siswa sehingga pembelajaran inspiratifnya lebih mengena dengan pemberian sumber belajar yang lebih terupgrade.

\section{Klasifikasi Model Desain Pembelajaran Inspiratif dan Evaluasi}

Tahapan ketiga atau terakhir ini terdiri dari 2 proses yaitu 1). Guru memahami desain model pembelajaran yang akan digunakan untuk pembelajaran inspiratif lalu mengaplikasikan model agar menjadi pembelajaran inspiratif. Model pembelajaran dalam pengaplikasiannya memerlukan improvisasi agar mengena pada kebutuhan siswa, pengabdi akan membantu guru untuk berimprovisasi dengan model pembelajaran yang dipilih sesuai dengan konsep pembelajaran inspiratif. Proses terakhir adalah 2) Evaluasi terstruktur untuk mengetahui perkembangan desain yang telah dilakukan. Evaluasi sangat penting dalam pengajaran karena untuk guru terbiasa menilai kembali sejauh mana proses keberhasilan dari pengajaran yang diterapkan.

Dari pembahasan diatas, maka berikut rincian hasil yang dicapai dari pelaksanaan pelatihan sekaligus pembinaan yang dapat diuraikan bahwa dari 20 peserta yang mengukuti program pelatihan pembelajaran inspiring, melihat dari hasil selama pelatihan oleh team pengabdi dan pemantauan intens termasuk penilaian menggunakan angket yang dilakukan oleh mahasiswa KKN, dapat diuraikan sebagai berikut : 1) Peserta mendapatkan motivasi dalam mengajar pada masa pandemic ini dibuktikan dengan hasil progress yang menunjukan presentase keberhasilan sebanyak 85,7\%. 2) Peserta mendapatkan informasi bagaimana proses pendidikan yang berjalan saat ini di masa pandemik dilihat dari beberapa sekolah dan daerah, ini dibuktikan dengan hasil progress yang menunjukan presentase keberhasilan sebanyak $74,6 \%$. 3) Peserta memahami dan memiliki pengetahuan mengenai program pengajaran Inspiring Teaching, ini dibuktikan dengan hasil progress yang menunjukan presentase keberhasilan sebanyak $89,7 \%$. 4) Peserta memahami perubahan cara mengajar bagi siswa yang hidup di era modern, ini dibuktikan dengan hasil progress yang menunjukan presentase keberhasilan sebanyak $80,5 \%$. 5) Peserta dapat mengubah kebiasaan lama dalam mengajar seperti mengajar dengan cara mendikte dan ceramah harus diganti dengan pengajaran mendorong, memotivasi, mengarahkan, mengembangkan dan mengapresiasi, ini dibuktikan dengan hasil progress yang menunjukan presentase keberhasilan sebanyak 77,8\%.6) Peserta dapat mengaplikasikan metode pengajaran yang terbaru saat dikelas nanti, sehingga saat siswa harus belajar dari rumah, siswa secara mandiri mau dan sadar untuk belajar, ini dibuktikan dengan hasil progress yang menunjukan presentase keberhasilan sebanyak $78,3 \%$. 


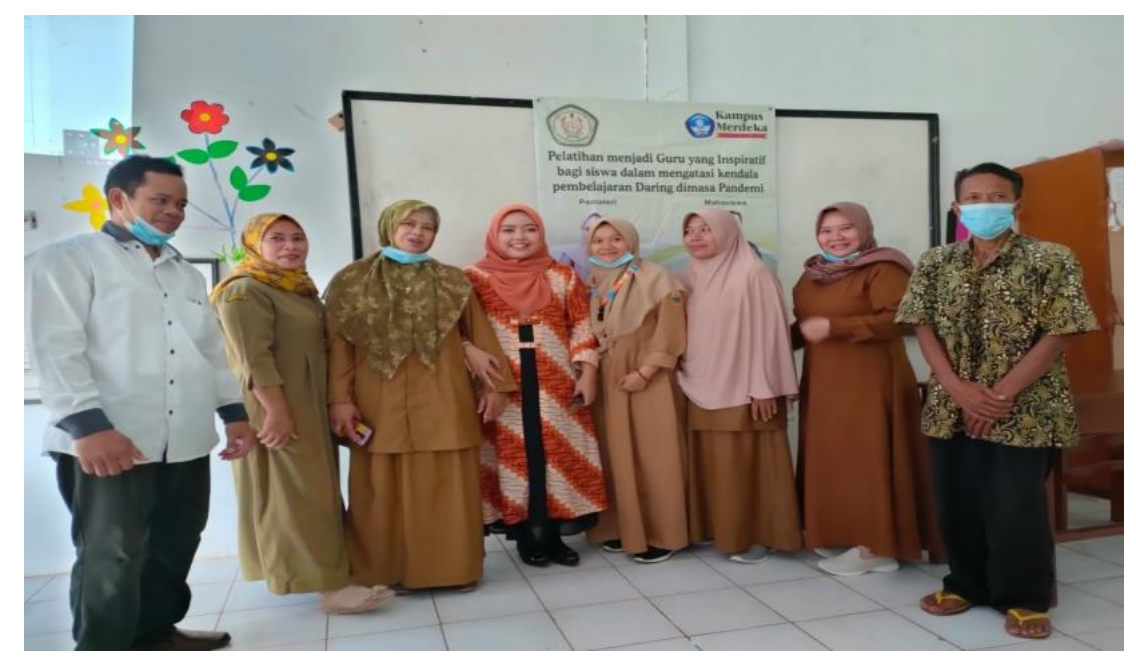

Gambar 3. Dokumentasi antara pemateri dan beberapa peserta

Adapun follow up setelah kegiatan pelatihan ini dilaksanakan yaitu :

1) peserta berkewajiban memahami teori terkait pengajaran yang menginspirasi dengan membuat RPP sesuai dengan metode pengajarn menginspirasi.

2) Peserta akan melakukan praktek pengajaran rutin yang dievaluasi oleh peserta KKN Tematik Mandiri yang kemudian diserahkan kepada dosen PGSD STKIP Syekh Manshur.

3) Peserta mengaplikasikan RPP yang baru dirancang dan tehnik pengajaran yang sudah dilatih kepada siswa saat dikelas.

Kegiatan pengabdian yang dilaksanakan di SDN Sangkanwangi 1 Kecamatan Leuwidamar ini memberikan respon positif dan progress yang baik bagi guru di SDN Sangkanwangi 1, selain diterima dengan baik oleh pihak sekolah baik itu kepala sekolah, komite dan para guru, kegiatan ini pun didukung oleh kepala kelurahan desa setempat. Guru di SDN Sangkanwangi 1 sangat antusias mengikuti kegiatan pembinaan yang pengabdi lakukan. Dengan dilaksanakannya kegiatan pelatihan sekaligus pembinaan ini, pemahaman Guru di SDN Sangkanwangi 1 Plus semakin bertambah kompetensinya dalam mengajar.

\section{Simpulan dan Rekomendasi}

Program pelatihan sekaligus pembinaan yang dilakukan di SDN Sangkanwangi 1 di atas, mendapatkan hasil yaitu peserta memahami mengenai program pelatihan Inspiring Teaching, selain itu peserta mulai mengubah kebiasaan lama dalam mengajar seperti mengajar dengan cara mendikte dan ceramah harus diganti dengan pengajaran mendorong, memotivasi, mengarahkan, mengembangkan dan mengapresiasi. Peserta mulai mengaplikasikan metode pengajaran yang terbaru saat dikelas saat mulai pembelajaran blended learning. Untuk harapan kedepannya guru di SDN Sangkanwangi 1 disarankan meningkatkan komptensi mengajarnya dan semakin mendalami Inspiring Teaching. Karena program ini sangat berguna untuk membantu guru dalam menghadapi perubahan sistem mengajar yang disebabkan pandemik ini. 


\section{Penghargaan}

Dalam proses pengabdian kepada masyarakat, tim pengabdian mendapat dukungan dan dukungan yang sangat berharga dari berbagai pemangku kepentingan. Untuk itu, kami ingin mengucapkan terima kasih dan penghargaan kepada:

1. STKIP Syekh Manshur Pandeglang yang telah mendukung pengabdian masyarakat ini.

2. Kepala SDN Sangkanwangi 1 bekerja sama dengan ketua dan guru panitia meluangkan waktu untuk menyukseskan pengabdian ini.

3. Seluruh pihak yang terlibat dalam kegiatan PKM ini.

\section{Daftar Pustaka}

Arifa, F. N. (2020). Tantangan Pelaksanaan Kebijakan Belajar Dari Rumah Dalam Masa Darurat Covid-19. Puslit, XII(7).

Basar, A. M. (2021). Problematika Pembelajaran Jarak Jauh Pada Masa Pandemi Covid-19. Edunesia: Jurnal Ilmiah Pendidikan, 2(1), 208-218. https://doi.org/10.51276/edu.v2i1.112

Kahfi, A. (2020). Tantangan Dan Harapan Pembelajaran Jarak Jauh Di Masa Pandemi Covid 19. Dirasah, 03(2), 137-154. https:/ / stai-binamadani.e-journal.id/jurdir

Morrison, G. R., Ross, S. M., \& Kemp, J. E. (2001). Designing effective instruction (3rd ed.). John Wiley.

Pamela Sammons, Ariel Mariah Lindorff, Lorena Ortega, A. K. (2014). Inspiring teaching: learning from exemplary practitioners. Jiurnal of Professional Capital $\mathcal{E}$ Community.

Rohani, S. (2013). Menjadi Guru Yang Inspiratif Pada Sekolah Islam Al Syukro Universal. 30.

Shen, T. (2012). Inspiring the Creativity and Imagination of University Students During Creative Curriculum by Teaching Design. Procedia - Social and Behavioral Sciences, 45, 615-620. https:/ / doi.org/10.1016/j.sbspro.2012.06.599

Slameto, S. (2015). Pembelajaran berbasis riset mewujudkan pembelajaran yang inspiratif. Satya Widya, 31(2), 102-112.

Sutarman, A., Wardipa, I. G. P., \& Mahri, M. (2019). Penguatan Peran Guru di Era Digital Melalui Program Pembelajaran Inspiratif. Tarbawi: Jurnal Keilmuan Manajemen Pendidikan, 5(02), 229. https:// doi.org/10.32678/tarbawi.v5i02.2097

Williams, L., Nixon, S., Hennessy, C., Mahon, E., \& Adams, G. (2016). Inspiring to inspire: Developing teaching in higher education. Cogent Education, 3(1). https://doi.org/10.1080/2331186X.2016.1154259 